\title{
THE LIVING STANDARD OF MINERS IN BISCAY (1876-1936): WAGES, THE HUMAN DEVELOPMENT INDEX AND HEIGHT*
}

\author{
ANTONIO ESCUDERO \\ University of Alicante ${ }^{\mathrm{a}}$ \\ PEDRO M. PÉREZ CASTROVIEJO \\ University of the Basque Country
}

\begin{abstract}
Recent research on working-class living standards during the Industrial Revolution has shown that wages do not cover all welfare components - for instance, working conditions, leisure time or the "access rights» needed make one prosper (health, education and freedom). This is why studies have been published in which wages are compared with other living standard indicators. Following this line of research, our paper examines the evolution of welfare among Biscayan miners between 1876 and 1936 by contrasting real wages, Human Development Index and height. An additional contribution of the paper is that we relate the high morbi-mortality in the Biscayan working-class neighbourhoods with market failures derived from urbanisation, a connection not explicitly considered in the literature on living standards during the Industrial Revolution. These market failures were known by liberal politicians because the hygienists urged the intervention of the State to correct or, at least, ease them. However, the town councils in the Bilbao

* Received 21 December 2009. Accepted 18 March 2010. Pedro M. Pérez Castroviejo has benefited from the help of the project I+D (SEJ2007-67613/ECON, Ministerio de Ciencia e Innovación): «Crecimiento, nutrición y bienestar en España. La influencia de los procesos socioeconómicos a largo plazo en los niveles de vida biológicos y la salud».

a Departamento de Fundamentos del Análisis Económico, Universidad de Alicante, Campus de San Vicente, 03080 Alicante, Spain. escudero@aea.ua.es
\end{abstract}


mining zone took more than 20 years to put into practice the measures proposed by the hygienists.

Keywords: living standard, wages, human development index, height, market failures, biscay

JEL Code: N33, N34

\section{RESUMEN}

Recientes investigaciones sobre el nivel de vida de la clase obrera durante la Revolución Industrial han demostrado que el salario no capta todos los elementos del bienestar - por ejemplo, condiciones laborales, tiempo de ocio o «derechos de acceso» necesarios para prosperar (salud, educación y libertad). De ahí que se hayan publicado trabajos que comparan el salario con otros indicadores del nivel de vida. Siguiendo esta línea de investigación, nuestro artículo estudia la evolución del bienestar de los mineros de Vizcaya entre 1876 y 1936 contrastando salarios reales, IDH y estatura. Otra aportación del artículo es que relacionamos la elevada morbi-mortalidad en los barrios obreros mineros de Vizcaya con fallos de mercado derivados de la urbanización, algo que no aparece de modo explícito en los trabajos sobre el nivel de vida durante la Revolución Industrial. Esos fallos de mercado eran conocidos por los políticos liberales porque los higienistas exigieron la intervención del Estado para corregirlos o cuando menos paliarlos. Sin embargo, los ayuntamientos de la zona minera de Bilbao tardaron más de veinte años en llevar a la práctica las medidas propuestas por los higienistas.

Palabras clave: nivel de vida, salarios, Índice de Desarrollo Humano, estatura, fallos de mercado, vizcaya

\section{INTRODUCTION}

Research into working-class living standards during the industrialisation period has proved that, as wages are a welfare input and not an output, they cannot capture all its elements - for example, working conditions, leisure time or the «access rights» needed to make one prosper (health, education and freedom $)^{1}$. This is why some works have been published in which wages - or

1 Regarding the inconveniences associated with the use of income as a welfare indicator, see the pioneering work of Norhdaus and Tobin (1973). For «access rights», see Dasgupta (1993) and Sen $(1998,2000)$. Referring specifically to research on living standards of the British working class 
per capita income - are compared with other living standard indicators (Quality of Life Physical Index, Human Development Index (HDI), Dasgupta and Weale or average height $)^{2}$.

In previous studies, the authors of this paper examined the well-being of Biscayan miners in terms of the evolution of real wages (Pérez Castroviejo 1992; Escudero 1998). The current paper, however, offers innovations that can contribute to improving our previous studies. The first is a more reliable series of real wages constructed with new nominal wages and a new cost of living index ${ }^{3}$; the second is an HDI; and the third is the evolution of the standardised height at the age of 21 years ${ }^{4}$. A fourth innovation lies in the fact that, following the research line mentioned above, we have analysed miners' welfare comparing these three indicators. To these innovations a fifth one can be added: in our opinion, the high morbi-mortality that devastated the Biscayan mining areas during the 1880 s and 1890 s was due to market failures derived from urban development, a hypothesis that does not appear explicitly in the works about living standards during the industrialisation period. These market failures should have been palliated by the intervention of the public powers; however, it took them two decades to act. It goes without saying that this last aspect can open a research line that exceeds the scope of this paper: why did it take the liberal politicians so long to put into practice the measures that the hygienists had proposed to reduce morbi-mortality in working-class neighbourhoods?

Our paper is structured as follows. We thought it appropriate to include a brief initial section dedicated to the expansion (1876-1913) and decline (1914-1936) of mining in Biscay. Next, we offer the series of real wages, HDI

(F'note continued)

during the Industrial Revolution, the modest growth of real wages (Feinstein 1998; Clark 2001) was not accompanied by a decrease in infant mortality (Kuh and Davey Smith 1993; Huck 1995); a higher life expectancy in working class quarters (Szreter and Mooney 1998) or better working conditions (Voth 2001), and no consensus has been reached about whether or not the literacy rate among the working classes improved (Sanderson 1991). The relationship between real wages and other welfare elements has been one of the key issues in the long controversy between «optimists» and "pessimists». A summary of this controversy can be found in Escudero (2002) and Voth (2004).

2 Examples of research works that use the Quality of Life Physical Index are those of Federico and Toniolo (1991) and Dominguez Martin and Guijarro Garvi (2000). Long HDI series for several countries can be found in Costa-Steckel (1997), Crafts (1997a, 1997b, 2002), Floud and Harris (1997), Horlings and Smits (1988), Escudero-Simón (2003) and Astorga et al. (2005). Crafts (1997a) has estimated Dasgupta-Weale Indices for some European countries between 1760 and 1860. The bibliography for the evolution of height during the industrialisation period is mentioned below (footnote 43).

3 The nominal wages corresponding to the 1876-1900 period offered in a previous paper (Escudero 1998) came from sources that were less reliable than the ones used in this paper and did not cover all the years. On the other hand, the cost of living index with which those wages were deflated only contained seven food items, the consumption of which was weighted using information from family budgets (Pérez Castroviejo 1992).

4 Pérez Castroviejo (2006) presented a miners' height series, but it was not standardised at 21 years of age. 
and height, after which an examination is made of the living standard during the two periods identified, with the sector's expansion and decline stages. The paper ends with a systematisation of some conclusions, which prove the fertility of contrasting several indicators and are in tune with recent research studies on workers' welfare during the Industrial Revolution. We also insist, in the last section, on the convenience not only of writing monographs about living standards using this technique of comparing several indicators, but also of examining the reasons why the liberal politicians ignored the hygienist doctors for decades.

\section{EXPANSION AND DECLINE OF IRON MINING IN BISCAY ${ }^{5}$}

In 1876, Biscay produced 400,000 tons of phosphorus-free iron ore. The average production during the 1880 s was 3.5 million tons. The figure of 5 million tons was reached at the end of the century and 4 million tons were extracted in 1913. However, production dropped to an average 2.8 million tons during the World War I and fell even more between 1919 and 1936, with an average 1.7 million tons of iron ore being mined.

In all, 75 per cent of the iron ore was shipped to Great Britain between 1876 and 1913. Therefore, the sector's expansion cycle must be explained by the huge British demand. 78 per cent of the steel manufactured in Great Britain during those years was Bessemer or acid Martin-Siemens steel. This preference for acid systems made British steel technologically dependent on phosphorus-free iron ores. Pure ores like those from Biscay were then exploited in Cumberland-Lancashire, in some Swedish ore bodies, in Spain (Santander and the Penibetic Range) and in Greece. Nevertheless, the production of these mining areas was insufficient to cater for the whole British demand, as a result of which and due to the shortage in the supply of alternative minerals, the demand for Biscayan ore became inelastic between 1876 and 1913. This is the key aspect that explains the expansion within this sector. The increase in Britain's production of acid steels pulled with it both the demand for Biscayan ore and its prices. Profits grew and so did ore production and the amounts of factors used - in the case of the labour factor, the number of workers rose from 950 in 1876 to over 8,000 during the 1890s and then to 12,000 in 1913.

The decline of the Biscayan mining industry stemmed from the technological change introduced by the British iron and steel industry during the World War I and was aggravated during the post-War period as a result of the modifications experienced in the demand for steel inputs. Between 1914 and 1918, Great Britain had to replace phosphorus-free iron ore imports due to the rise in freight prices. To this end, the iron and steel industry enterprises

\footnotetext{
${ }^{5}$ For a history of iron mining in Biscay between 1876 and 1936, see Escudero (1998).
} 
received help from the government to build basic Martin-Siemens furnaces, which extracted domestic phosphorous minerals as well as phosphorous scrap metal. Once the factories had been equipped with the new technology, 70 per cent of the steel they produced between 1919 and 1936 was basic Martin-Siemens steel because its costs were lower than those associated with acid steel. The reason for this difference lies in the prices of their respective inputs. At that time, basic Martin-Siemens furnaces consumed 70 per cent of phosphorous scrap metal - cheaper than pig iron after the war, as a result of its oversupply - and 30 per cent of pig iron, which was cheaper than acid steel because it was obtained from phosphorous minerals extracted in relatively young mining areas (Lincolnshire, the Midlands and Nordic and French imports). Instead, acid Martin-Siemens furnaces consumed phosphorus-free scrap metal - the price of which was higher than that of the phosphorous one due to its relative shortage - and acid pig iron, which was more expensive than the basic one because it was obtained from pure minerals found in old mining areas subject to decreasing performances (Cumberland-Lancashire and Spanish deposits). In turn, Bessemer converters required 100 per cent of acid pig iron, which cost more than basic pig iron and scrap metal. The construction of Martin-Siemens furnaces was consequently the key factor triggering the decline of the Biscayan mining industry, «protected» until 1913 by British loyalty to acid systems. These furnaces provided the British demand for steel inputs with elasticity and made acid steel production plummet, which had a very strong impact on the demand and prices of ore from Biscay. Profits dropped and so did ore production and the amounts of factors used - in the case of the labour factor, the number of workers fell from 12,000 in 1913 to an average 6,000 between 1914 and 1936.

\section{THREE INDICATORS OF THE LIVING STANDARD OF MINERS IN BISCAY (1876-1936)}

Building a rigorous series of miners' real wages requires the availability of nominal wages obtained from reliable sources and a cost of living index that takes into account the following aspects: (i) retail prices and those in the mining area corresponding to the goods and services consumed by miners; (ii) the relative importance that each one of those goods and services had in their consumption; and (iii) the variations in the demand derived from the Engel law ${ }^{6}$.

\footnotetext{
${ }^{6}$ One of the themes dealt with in the debate about the living standard of the British working class during the Industrial Revolution has been the conditions that an estimate of real wages must fulfil. See, for example, Flinn (1974), Lindert-Williamson (1983), Crafts (1985), Scholliers (1989), Feinstein (1998) and Clark (2001).
} 
FIGURE 1

NOMINAL WAGES OF MINE WORKERS IN BISCAY (1876-1936)

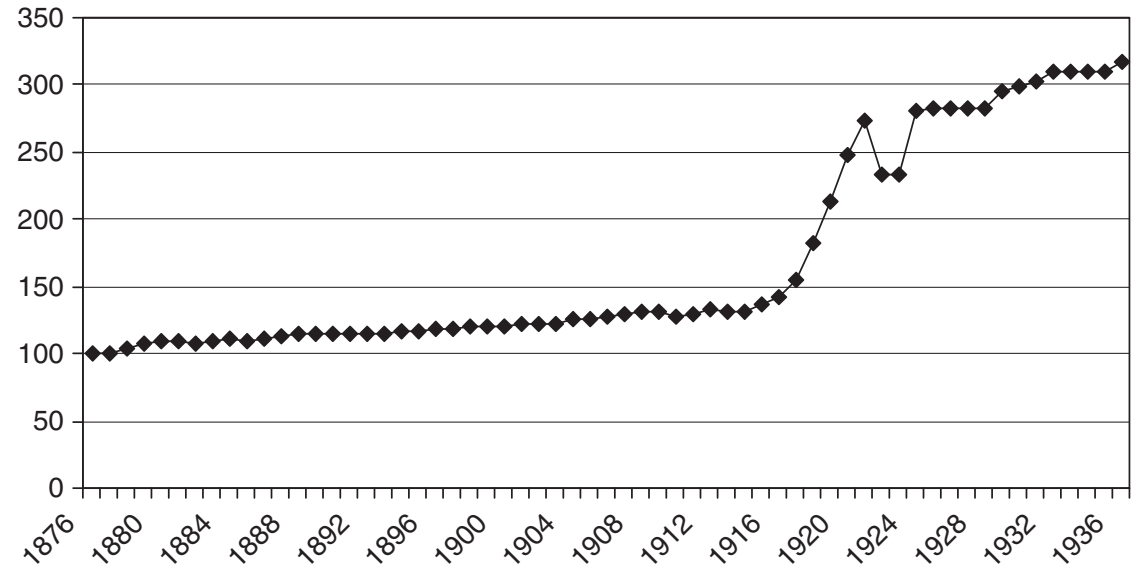

Source: See text and Table A1.

Table A1 and Figure 1 show the annual series of daily wages for workers in Biscayan mines (this unskilled labour represented 80 per cent of workers in this sector $)^{7}$. Although these wages did not always come from payroll books, the sources used are reliable. Those corresponding to the 1876-1899 period were found in two reports about mines in Bilbao written by engineers working for the Financial Studies of Crédit Lyonnais ${ }^{8}$. Two tables prepared by them show the highest and lowest wages paid each year to the workers of the two largest companies in the sector, Orconera Iron Ore and Franco Belga des Mines de Somorrostro, according to the data provided by the respective offices. The nominal wages corresponding to the 1876-1899 period are the arithmetic mean of the average daily wages paid by these two firms. Those corresponding to the years between 1900 and 1921 are the arithmetic mean of the daily wages obtained from another three sources: the Council of the mining town of San Salvador del Valle, two employers' organisations (the Asociación de Patronos Mineros and the Círculo Minero) and the payroll books of the mines exploited by

7 As it was an opencast mine, the workers' task consisted of using drop hammers to break the large blocks of rock which resulted from explosions, classifying the mineral according to size, transporting it in baskets and loading it in the inclined plane or endless chain dump trucks that took it to the railway. For working techniques in Biscayan mines, see Escudero (1998).

8 Historical Archive of Crédit Lyonnais (Paris): «Mines de fer de Bilbao», Rapport de mission (1890 and 1899), Box 20.152. The Financial Studies Survey of Crédit Lyonnais was created in 1871 for the purpose of providing the bank with national and international information about firms, public debt, stock markets and exchange rates. The purpose of this service, its highly skilled staff and the fact that the rapports de mission were carried out «in situ» guarantee the reliability of this source. 
FIGURE 2

COST OF LIVING IN THE RIA DE BILBAO INDUSTRIAL AREA (1876-1936)

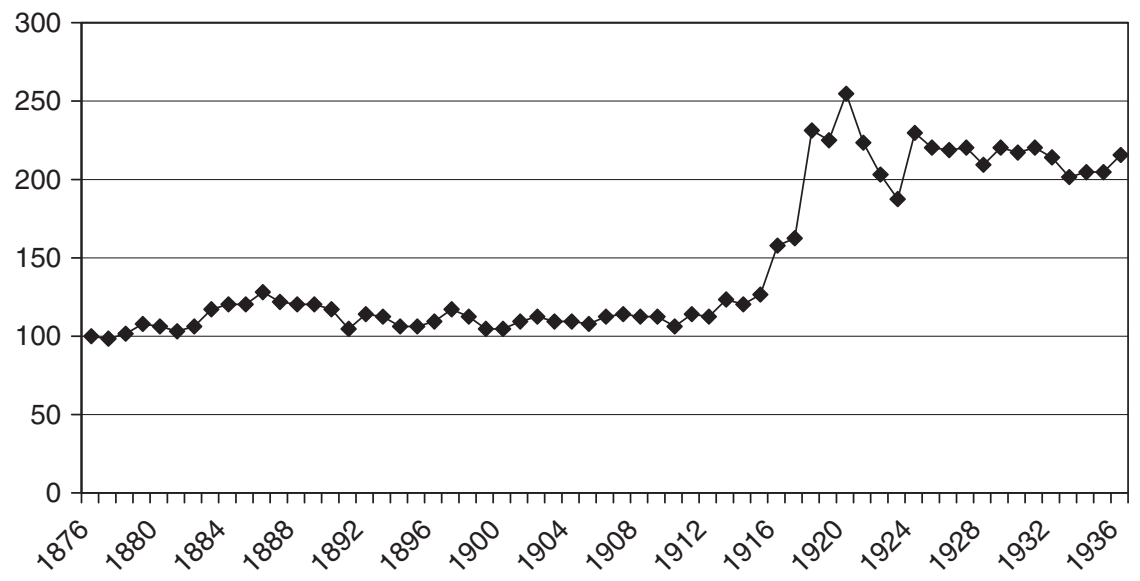

Sources: See Table A1. Pérez Castroviejo (2006).

the iron and steel firm Altos Hornos de Vizcaya 9 . Finally, the wages for the 19221936 period are the arithmetic mean of those found in the payroll books of the Ollargan mine and in the Memorias de la Cámara Minera de Vizcaya ${ }^{10}$.

The cost of living index used to transform nominal wages into real ones appears in Table A1 as well as in Figure $2^{11}$. The index corresponds to the Ría de Bilbao (Bilbao estuary) area, where the mines and the iron and steel industry, the metal-mechanical industry, the chemical industry and the shipyards were located. The prices are retail ones and they come from municipal sources, hospitals and dwelling rent registers ${ }^{12}$. The goods and services consumed by the Biscayan working class and their weighting appear in Table 1, which was

9 The San Salvador del Valle Council series (1900-1915) can be found in Pérez Castroviejo (1992); the series corresponding to the two employers' organisations (1900-1915) in Escudero (1998); and the daily wages from the payroll books of Altos Hornos de Vizcaya (1900-1915) in Fernández de Pinedo (1992).

${ }^{10}$ The daily wages paid in the Ollargan mine can be seen in Pérez Castroviejo (2006) and those of the Cámara Minera in Escudero (1998).

11 This cost of living index was constructed by Pérez Castroviejo (2006) and Pérez Castroviejo and Tusell (2007).

12 The prices of food items correspond to the municipalities of Bilbao and Baracaldo and come from several municipal sources - Boletín Oficial de la Provincia de Vizcaya (1876-1890), Baracaldo Council (1891-1927), Boletín Municipal de Estadística de Bilbao (1928-1936) — as well as the Basurto Hospital for bread (1876-1890) and a hospice, the Santa Casa de la Misericordia in Bilbao, for potatoes (1876-1890). Prices for rented accommodation were obtained from the Padrones de Cédulas Personales (1876-1903) and the Anuarios de la Dirección General de los Registros Civil y de la Propiedad y del Notariado (1904-1936), with the support of the Estadística de la Vivienda collected in the Nomenclatores that were carried out with 
TABLE 1

COMPOSITION OF BISCAYAN WORKING-CLASS EXPENDITURE (1876-1936)

\begin{tabular}{|c|c|c|c|c|}
\hline \multirow[b]{2}{*}{ Items } & \multicolumn{2}{|c|}{$1876-1905$} & \multicolumn{2}{|c|}{ 1906-1936 } \\
\hline & $\begin{array}{c}\text { Group } \\
\text { total }\end{array}$ & $\begin{array}{c}\text { Sub-group } \\
\text { total }\end{array}$ & $\begin{array}{c}\text { Group } \\
\text { total }\end{array}$ & $\begin{array}{c}\text { Sub-group } \\
\text { total }\end{array}$ \\
\hline Food & 70 & 100 & 63 & 100 \\
\hline Bread & & 38 & & 28 \\
\hline Meat & & 19 & & 21 \\
\hline Wine & & 11 & & 9 \\
\hline Oil & & 6 & & 8 \\
\hline Pulses & & 15 & & 11 \\
\hline Rice & & 4 & & 4 \\
\hline Potatoes & & 7 & & 8 \\
\hline Sugar & & - & & 2 \\
\hline Fresh fish & & - & & 4 \\
\hline Milk & & - & & 3 \\
\hline Egg & & - & & 2 \\
\hline Rent & 13 & 100 & 14 & 100 \\
\hline Clothing & 7 & 100 & 10 & 100 \\
\hline Cotton cloth & & 100 & & 60 \\
\hline Linen cloth & & & & 20 \\
\hline Wool & & & & 20 \\
\hline Cleaning and hygiene & 4 & 100 & 5 & 100 \\
\hline Soap & & 100 & & 100 \\
\hline Fuel and power & 6 & 100 & 8 & 100 \\
\hline Vegetal coal/firewood & & 100 & & 45 \\
\hline Mineral coal & & & & 45 \\
\hline Electricity & & & & 10 \\
\hline
\end{tabular}

Source: Pérez Castroviejo (2006).

\section{(F'note continued)}

some Censos de Población. The prices of clothing, soap, fuel and power (coal, firewood, electricity) come from the Basurto Hospital Diario books and are not contractual prices. 
constructed using more than twenty family budgets, information from official institutions and documents obtained from the Hospital de Basurto and the Santa Casa de Misericordia hospice in Bilbao ${ }^{13}$. Once the prices and the composition of the expenditure were known, the cost of living index was obtained using a Laspeyres-type formula (Pérez Castroviejo 2006).

The evolution of the cost of living index for the Ría de Bilbao (Figure 2) resembles the situation for Spain and other regions: a modest price growth between 1876 and 1913 - despite which prices in the Ría de Bilbao grew more than in Spain as a whole during the 1880s — an inflationist «gap» during the World War I and the post-war period and finally, a drop, though remaining at a much higher level than in $1913^{14}$. In turn, the composition of the working-class family expenditure shown in Table 1 is similar to that identified in Spain and other regions by some colleagues and does not differ much from the situation in Great Britain during the Industrial Revolution ${ }^{15}$.

Nominal wages and the cost of living index have helped us to estimate the first indicator of miners' living standard: their real wages (Table A1 and Figure 3).

The second indicator - their HDI - appears in Table 2.

We will first mention the sources of the figures, after which we will describe how the HDI was calculated. In the absence of data for life expectancy in the eminently mining towns, we decided to use a "proxy»: the life expectancy at birth in Sestao and Baracaldo calculated by María Eugenia González Ugarte and Mercedes Arbaiza ${ }^{16}$. Since these two towns were the most densely populated ones in the Bilbao industrial area, where the mining villages were also located, taking additionally into account that there were also mining quarters in Baracaldo, it seems reasonable to extrapolate that life expectancy to the case examined in the present paper. Literacy rates come from the Censos de la Población Española and are the weighted average of the seven eminently mining towns (Abanto and Ciérvana, Galdames, Güeñes, Musques, San Salvador del Valle and Sopuerta) and of another three with mining quarters (Baracaldo, Basauri and Santurce) ${ }^{17}$.

13 See a list of these sources in Pérez Castroviejo (2006).

14 Cost of living indices for Spain can be seen in Ballesteros (1997) and more recently in Maluquer de Motes (2005); regional cost of living indices in Moreno Lázaro (2006) for Old Castile; in Lana Berasaín (2005) for Navarre; and in Molina de Dios (2003) for Majorca.

15 Working class expenditure structures in Spain for the period under study can be found in Simpson (1995), Ballesteros (1997), and Maluquer de Motes (2005); in Lana Berasaín (2005) for Navarre; in Moreno Lázaro (2006) for Old Castile; and in Molina de Dios (2003) for the Balearic Islands. For figures for Great Britain during the Industrial Revolution, see Horrel (1996) and Feinstein (1998).

16 Gonzalez Ugarte (1994) offers life expectancy figures for Sestao and/or Baracaldo, and Arbaiza (1995), for Baracaldo. The life expectancy in Table 2 is the average between Sestao and Baracaldo in 1877, 1890, 1910, and 1930. The figures for 1895 and 1900 correspond to Baracaldo and that for 1925 to Sestao.

17 The 1877, 1900, 1910 and 1930 rates come from the censuses of those years. The 1890 figure is that given in the 1887 census. That for 1895 is the average of the rates found in the 1887 and 1900 
FIGURE 3

REAL WAGES OF MINE WORKERS IN BISCAY (1876-1936)

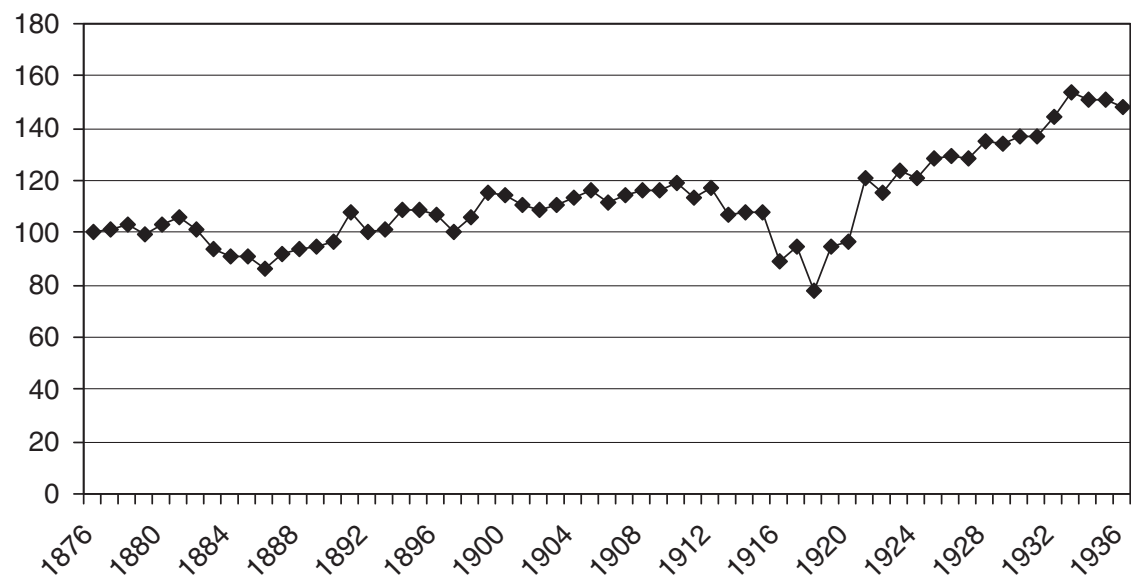

Source: See Table A1.

Estimating the income per person component is complicated because there is no information available for family income that can be divided by a figure that we do know, that corresponding to the average family size (4.7 individuals $)^{18}$. However, the Male Breadwinner Family model was the predominant one because there was very little child and female work in mines only 6 per cent of the workers were boys between 14 and 16 years of age and only 2 per cent women ${ }^{19}$. It thus seems reasonable to use the annual income obtained by the head of the family divided by 4.7 as a "proxy» ${ }^{20}$. The income component estimated in this way is biased downward, since an undetermined number of families obtained more money because the women exercised wardship, but, as we have explained, it seems sensible to use the figures appearing in column 3 of Table $2^{21}$.

\footnotetext{
(F'note continued)

censuses, while that for 1925 corresponds to the average between the rates found in the 1920 and 1930 censuses. The source used made it necessary for us to define a literate person as «someone who can read or read and write» as opposed to the alternative of «someone who can both read and write».

${ }_{18}$ Arbaiza (1995) has studied the average size of households using the Padrones de Población (population registers).

19 The female labour worked on the hand-selection lines of «trommels» (mud removers) and the boys («juniors») at classification and hand-picking (Escudero 1998, pp. 210-212).

20 To estimate the head of the family's annual income, we have multiplied the real wage by the number of days worked per year, a total of 285 , since the mining employers' association estimated that this was the average number of days worked because, in addition to public holidays, work was cancelled on days with heavy rain.

21 On wardship, see Pérez Castroviejo (1992, 1994) and Pérez Fuentes (1993, 2003).
} 
TABLE 2

HDI OF BISCAYAN MINERS (1877-1930)

\begin{tabular}{|c|c|c|c|c|c|c|c|}
\hline & \multicolumn{3}{|c|}{ Original values } & \multicolumn{3}{|c|}{ Indices } & \multirow[b]{2}{*}{ HDI } \\
\hline Years & $\begin{array}{l}\text { Life expectancy } \\
\text { at birth (years) }\end{array}$ & $\begin{array}{l}\text { Literacy } \\
\text { rate }(\%)\end{array}$ & $\begin{array}{l}\text { Per capita income } \\
\text { (in constant dollars } \\
\text { of } 1990 \text { with PPP)* }\end{array}$ & $\begin{array}{c}\text { Life expectancy } \\
(\text { minimum }=19.9 \\
\text { years })\end{array}$ & $\begin{array}{l}\text { Literacy } \\
\text { rate }\end{array}$ & $\begin{array}{l}\text { Per capita income } \\
\text { (in constant dollars } \\
\text { of } 1990 \text { with PPP)* }\end{array}$ & \\
\hline 1877 & 36.5 & 40.90 & 479.6 & 0.277 & 0.409 & 0.262 & 0.316 \\
\hline 1890 & 19.9 & 44.10 & 464.3 & 0.000 & 0.441 & 0.256 & 0.232 \\
\hline 1895 & 29.2 & 47.50 & 521.8 & 0.155 & 0.475 & 0.276 & 0.302 \\
\hline 1900 & 30.4 & 48.9 & 546.7 & 0.175 & 0.489 & 0.284 & 0.316 \\
\hline 1910 & 39.1 & 57.40 & 569.8 & 0.320 & 0.574 & 0.290 & 0.395 \\
\hline 1925 & 49.6 & 65.6 & 613.9 & 0.495 & 0.656 & 0.303 & 0.485 \\
\hline 1930 & 50.3 & 68.10 & 656.1 & 0.507 & 0.681 & 0.314 & 0.501 \\
\hline
\end{tabular}

Notes: HDI: Human Development Index.

*We have transformed the constant pesetas of 1876 into constant pesetas of 1990 with the series of Prados de la Escosura (2003) and later applied the exchange rate with purchasing power parity in 1990 for the peseta and the dollar estimated by Maddison (1995).

Source: See text. 
The HDI was estimated according to the rules recommended by United Nations Development Programme (UNDP) for the calculation of the HDI but introducing two modifications: (i) no compound indicator of the education variable was used; the literacy rate was introduced instead ${ }^{22}$; (ii) we operated with minimum and maximum life expectancy values of 19.9 and 85 years, instead of 25 and 85, because the life expectancy in the mining area in 1890 was 19.9 years.

Military service was compulsory in Spain until very recently. All conscripts were measured at the town halls, including those who later managed to avoid military service by paying their «redemption» to the State ${ }^{23}$. In many cases, the local authorities have kept the so-called Actas de Clasificación y Alistamiento, in which the name of the conscript as well as his birthplace, profession and height are collected. Nevertheless, this rich documentation presents a problem: the changes in the recruitment age. While youngsters between 19 and 20 years of age were conscripted between 1856 and 1907, after 1907, young men were conscripted at the age of 21 years $^{24}$. This makes it necessary to standardise the height at the age of 21 years, because boys still grow between the ages of 19 and 21 years. A number of Spanish anthropometrists have standardised series adding to the average height of 19- and 20-year-olds, the average growth experienced by short youngsters, a growth that we know because these youngsters had to be measured for 3 years and their height at the age of 20 or 21 years was noted in the so-called Actas de Revisión (Martínez Carrión and Moreno Lázaro 2007; Cámara 2009; García Montero 2009; Martínez Carrión and Puche-Gil 2009; Ramon-Muñoz 2009; Hernández and Moreno Lázaro 2009).

For the purpose of determining the evolution of the average height of miners, we chose the height of the conscripts measured in the town of San Salvador del Valle as a "proxy» for two reasons:. first, because it was the largest mining town (6,500 inhabitants) and nearly 93 per cent of the conscripts were registered as jornaleros (mine workers); and second, because the documents corresponding to all the years between 1878 and 1935 have been preserved to the present day. The series was standardised using the recruitment certificate of 1885 because, due to special military needs, youngsters of different ages were measured that year. This information led us to increase by 0.55 centimetre the average heights of those measured at the age of

22 Crafts (1997a, 1997b, 2002), Floud and Harris (1997), Costa-Steckel (1995), Horlings and Smits (1988), Escudero-Simón (2003) and Astorga et al. (2005) have constructed a number of long HDI series for several countries introducing the literacy rate due to the difficulty involved in using the education indicator proposed by the UNDP for the $19^{\text {th }}$ century. On the other hand, the first UN reports also used the literacy rate as a «proxy» for the educational level.

23 The redemption (the right to avoid doing military service if a certain amount was paid to the State) was abolished in 1912.

${ }^{24}$ More precisely, between 1856 and the first call-up of 1885, 20-year-olds were measured; between the second call-up of 1885 and 1899, 19-year-olds were measured; in 1900, there were no recruitments; between 1901 and 1905, 20-year-olds were measured; in 1906, there were no recruitments either, and, finally, after 1907, 21-year-olds were measured. 
FIGURE 4

AVERAGE HEIGHT OF THE CONSCRIPTS MEASURED IN SAN SALVADOR DEL VALLE (1877-1935; 5-YEARLY AVERAGES IN CENTIMETRES)

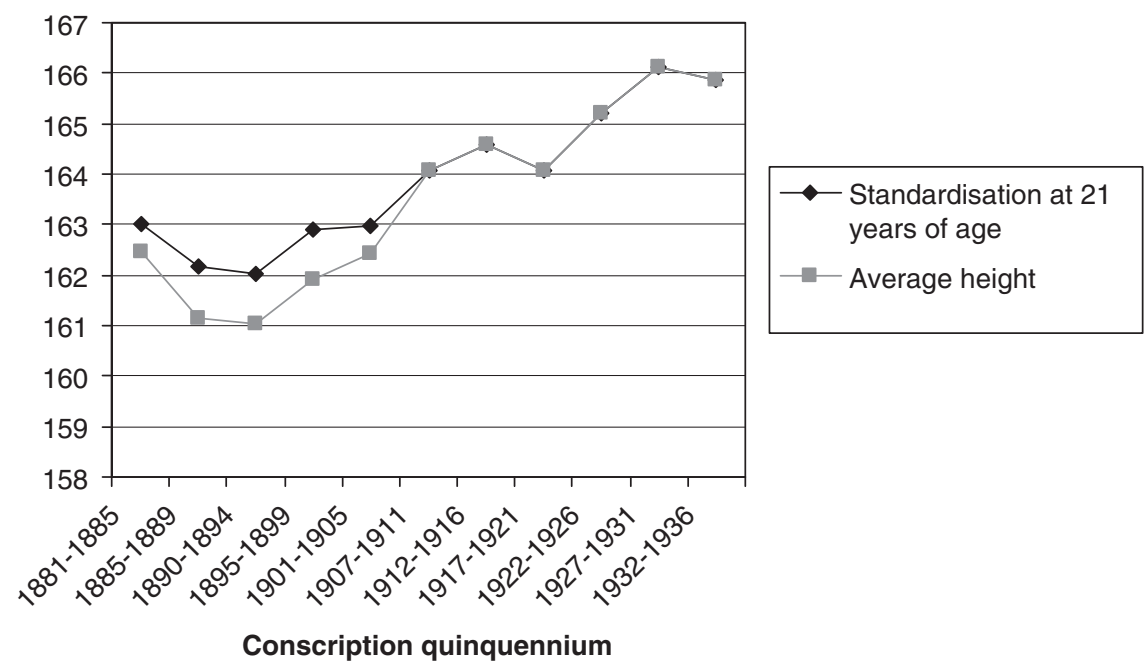

Source: See text and Table A2.

20 years and by 1 centimetre that of those measured at the age of 19 years, an increment similar to that estimated by the aforementioned anthropometrists. Table A2 and Figure 4 show the average height of the conscripts measured in San Salvador del Valle before and after standardisation at 21 years of age.

\section{THE LIVING STANDARD OF BISCAYAN MINERS (1876-1913)}

During the expansion cycle of the mining industry, workers' nominal wages increased at an average cumulative rate of 0.75 per cent (Table A1 and Figure 1). This weak growth can be justified by the existence of a labour market that was close to the perfect competition model, mainly from the point of view of atomicity (many demanders and suppliers of labour, none of whom could alter the balance wage). This atomicity was due to the weak power of unions - none of the workers' strikes for pay rises between 1876 and 1913 was successful - and to the non-existence of a monopolistic labour demand - mines were exploited by over 110 firms $^{25}$. Under these

25 For a study of social conflicts in Biscayan mines between 1876 and 1936, see Fusi (1975) and Escudero (2001). 
circumstances, the productivity increase made both labour demand and wages grow, but the latter only increased modestly as a result of the simultaneous increase in labour supply caused by the mass immigration into the mining districts from nearby farming areas with a zero marginal productivity $^{26}$. It is worth mentioning that - within the general context of sluggishness - the wages of Biscayan miners grew more than those of other unskilled Spanish workers (Table 3).

In Figure 3, it can be seen that the real wages of Biscayan miners decreased between 1883 and 1890 because the cost of living (Figure 2) increased by 20 per cent as a result of strong immigration flows and inelastic housing and food supply ${ }^{27}$. Real wages increased outside that period, but their growth was smaller than that of nominal wages: an average cumulative rate of 0.18 per cent between 1876 and 1913 and 0.35 per cent if one makes the 1876 wage per average 1909-1913 wage estimate to offset the disturbing effect of the last year ${ }^{28}$. This very slight increase is similar to that experienced by the real daily wage paid to other non-skilled Spanish workers ${ }^{29}$. Therefore, taking salary as an indicator, the welfare of Biscayan miners improved modestly between 1876 and 1913. However, it deteriorated during the 1883-1890 period.

Following the line of research mentioned in the introduction to the paper, we will first compare the real wages of miners with their HDI and then with their height. The HDI has the disadvantage that it weights each one of its three components at 33 per cent — which implies a value judgement — and the advantage that it collects two "access rights», which do not necessarily depend on income (health and education) ${ }^{30}$. Table 2 shows the HDI of miners. Let us look first at the evolution of each of its components until 1910, after which we will study the evolution of the indicator.

The evolution of the income component has already been analysed in the discussion of real wages: modest growth between 1877 and 1910 and a drop during the $1880 \mathrm{~s}$. The literacy rate rose from 40.9 to 57.4 per cent. This is a

26 Most of the immigrants came from Biscay and Burgos between 1876 and 1883. Later, they came from Old Castile, La Rioja, Navarra, and Galicia. On immigration into the mining areas, see Pérez Castroviejo (1986, 1992).

27 Of the items listed in Table 1, prices for rented accommodation increased by 300 per cent between 1883 and 1890 and those for food by 15 per cent.

${ }^{28}$ It can be observed in Table A1 that the real wage in 1913 was only 107 psesetas, because the cost of living increased ten points with respect to the previous years. It is thus reasonable to estimate the 1876/average 1909-1913 growth rate (real wage: 114 psesetas).

29 The few available real wage series elaborated with regional cost of living indices for the 18761913 period show small growth rates too. See Garrabou and Tello (2002) for farming labourers in Catalonia; Molina de Dios (2003) for farming labourers in Majorca; Pérez Picazo (2005) for farming labourers in Murcia; Lana Berasaín (2005) for farming labourers in Navarre; Pérez Castroviejo (2006) for the Biscayan iron and steel industry workers; and Moreno Lázaro (2006) for bricklayers in Palencia.

${ }^{30}$ Regarding the advantages and disadvantages of using the HDI, see Desai (1991), Streeten (1994) and Noorbakhsh (1998). 
TABLE 3

SPAIN. NOMINAL DAILY WAGES OF UNSKILLED WORKERS (1876-1913; PSESETAS)

\begin{tabular}{|l|c|c|c|c|c|c|c|}
\hline & $\begin{array}{c}\text { Miners: } \\
\text { Biscay (1) }\end{array}$ & $\begin{array}{c}\text { Miners: } \\
\text { Murcia (2) }\end{array}$ & $\begin{array}{c}\text { Miners: } \\
\text { Río Tinto } \\
\text { (Huelva; 3) }\end{array}$ & $\begin{array}{c}\text { Farming } \\
\text { laboures: } \\
\text { Inner Spain (4) }\end{array}$ & $\begin{array}{c}\text { Farming } \\
\text { labourers: } \\
\text { Navarre (5) }\end{array}$ & $\begin{array}{c}\text { Farming } \\
\text { labourers: } \\
\text { Coastal } \\
\text { Catalonia (6) }\end{array}$ & $\begin{array}{c}\text { Bricklayers. } \\
\text { Palencia (7) }\end{array}$ \\
\hline 1876 & 2.50 & 1.70 & 2.75 & 1.60 & 1.84 & 2.54 & 2.29 \\
\hline 1913 & 3.30 & 2.20 & 3.12 & 2.00 & 2.19 & 3.00 & 2.89 \\
\hline $\begin{array}{c}\text { Average } \\
\text { cumulative } \\
\text { rates }\end{array}$ & $0.75 \%$ & $0.69 \%$ & $0.33 \%$ & $0.60 \%$ & $0.47 \%$ & $0.44 \%$ & $0.62 \%$ \\
\hline
\end{tabular}

Sources: (1): Table A1; (2): Martínez Soto (2005); (3): Arenas Posadas (2000); (4): Bringas (2000); (5): Lana Berasaín (2005); (6): Garrabou and Tello (2002); (7): Moreno Lázaro (2006). 
small growth, which, however, exceeded that of Spain as a whole (36.2-49.7 per cent) for reasons of supply and demand. The demand for education is related to family income, child labour and parents' cultural level. In fact, the wages of Biscayan miners were among the highest paid to unskilled workers in Spain. There was little child labour in these mining areas, unlike the situation in farming and in the rest of the Spanish mining industry, where it reached 20 per cent ${ }^{31}$. Finally, and also contrary to the situation in other regions where illiteracy became a vicious circle, the higher literacy rate achieved in the Biscayan mining areas favoured an improvement in schooling levels ${ }^{32}$. In addition, the Biscayan municipalities created more school places than those located in other Spanish regions (Núñez 1992).

The evolution of life expectancy shows that, until the early $20^{\text {th }}$ century, mortality was higher than before industrialisation. Surprising as it might seem, the life expectancy figure for 1890 (19.9 years) is not a misprint ${ }^{33}$. The population in the industrial and mining area trebled between 1876 and 1900; with one case, the mining town of San Salvador del Valle, the number of inhabitants are actually multiplied by $\operatorname{six}^{34}$. This human landslide caused by immigration had negative consequences (contaminated water and overcrowding), which, together with the sale of food in bad condition, considerably increased the risk of disease and, consequently, the mortality rate. As we are trying to explain below, the three problems derived from market faults, which would have required rapid state intervention, which unfortunately came too late.

Between 1876 and the early $19^{\text {th }}$ century, the Town Councils in the mining areas permitted the construction of buildings without simultaneously building a water supply infrastructure and sewer system, a situation criticised by engineers and hygienist doctors from Bilbao, who warned that it would bring water contamination and an increased morbi-mortality as consequences $^{35}$. Therefore, knowing these consequences - a market failure that we call «negative externality» nowadays - the public powers should have built the infrastructure of water supply and the sewer system or, failing

${ }_{31}$ For child labour in the Spanish mining industry, see Pérez de Perceval-Sánchez Picón (2005).

32 A history of literacy campaigns in Spain can be found in Núñez (1992).

33 On mortality in the industrial and mining area, see Pérez Fuentes (1993), Gonzalez Ugarte (1994), Arbaiza (1995), Arbaiza et al. (1996) and Pérez Castroviejo (2005).

${ }^{34}$ The population of the industrial and mining area increased from 13,521 inhabitants in 1877 to 50,904 in 1900; that of mining municipalities, from 7,383 to 25,058; and that of San Salvador del Valle, from 1,033 to 6,748. The figures are from the Censos de la Población Española.

${ }^{35}$ Numerous works of hygienists can be found in the Bilbao press of the time and in Revista de Obras Públicas (Public Works Review). By way of example, this review published - beginning in the early 1880 s - works about the need for a sewer system in the Bilbao quarters signed by engineers such as Churruca, Alzola and Ubagón Bedía. Similarly, in 1886, the Orconera Iron Ore engineer William Gill suggested constructing a sewer system in the mining areas in a brochure entitled Higienizar Triano (Hygienising Triano) and the English hygienist Teale's book, La Salud en Peligro (Health in Danger) was published in Bilbao that same year. For more information about hygienism in Bilbao, see Pérez Fuentes (1991). 
that, should have encouraged construction by private firms ${ }^{36}$. In the case of food in bad condition, the market fault derived from an imperfect information flow. The hygienist doctors of the time explained how manipulation, poor hygienic conditions in warehouses and shops and adulteration resulted in the sale of food in bad condition that consumers could not recognise (see Arbaiza 1995; Pérez Castroviejo 2006). Therefore, the public authorities should have acted as regulators of economic activity. However, sanitary inspection in markets and bromatological control in laboratories did not become widespread until the end of the $19^{\text {th }}$ century or at the beginning of the $20^{\text {th }}$ century ${ }^{37}$.

The problem of overcrowding can be attributed to a housing supply that acquired elasticity only in the long term. The literature regarding the construction economy shows that the housing supply was inelastic in the short $t^{2} \mathrm{sm}^{38}$. If we add to this structural problem the fact that the demand for flats «soared» due to the rapid population growth, it can be understood why rent prices increased fourfold between 1876 and 1900. This forced working-class families to turn to board and lodging, thus generating serious overcrowding problems $^{39}$. We are thus faced by two market failures: the slowness of the market under certain circumstances when it comes to offering a preferential good like housing; and the negative externalities that overcrowding causes on health. In these conditions - and following the hygienists' recommendations - the public powers should have built cheap dwellings, which they did not do until the early $20^{\text {th }}$ century (Pérez Castroviejo 1994; Domingo Herández 2008).

The aetiological studies carried out by González Ugarte (1994) and Arbaiza (1995) show that the three above-mentioned factors account for the extremely high mortality rate during the last third of the 19th century, as 84 per cent of deaths were caused by infectious diseases propagated through the air or via consumption of water or food in bad condition (González Ugarte 1994; Arbaiza 1995). In contrast, the gradual disappearance of these three problems in the early $20^{\text {th }}$ century justifies the reduction of mortality and the start of the demographic transition in the Biscayan industrial and mining area.

36 The sewer system in the mining areas, for example, started to be built in the late 1890s and was finished in 1906. See Pérez Castroviejo (2006).

37 Regarding food sanitary inspection, see Pérez Castroviejo (2006).

38 The problem with the construction of housing is that it requires the fulfilment of a number of previous conditions that delay its completion (preparation of the project, purchase of the land, building licences, bank loans, contracting a building firm and an execution time that is seldom less than 2 years). Although there are numerous studies that explain why the adjustment in the real estate markets does not take place in the short term, we will highlight that of Smith et al. (1988). For working-class housing problems during the industrialisation period, see Burnett (1980) and Rule (1986).

39 On prices of rented accommodation, see Pérez Castroviejo (2006). For overcrowding problems, see Pérez Castroviejo (1992, 1994), Pérez Fuentes (1993) and Arbaiza (1995). 
Following this analysis of the evolution of its components, let us now look at the evolution of the HDI between 1877 and 1910 (see Table 2):

(1) According to the UN conventional values, an HDI above 0.8 indicates a high welfare level; one situated between 0.5 and 0.8 , an average welfare level and, finally, an HDI below 0.5 would indicate a low welfare level. In other words, Biscayan miners did not reach what is currently considered an intermediate living standard until the 1930s.

(2) The HDI declined from 0.316 to 0.232 between 1877 and 1890, a remarkable decrease mainly caused by the decrease in life expectancy and, secondarily, by the drop in income. Indeed, life expectancy evolved from a 0.277 index (36.5 years) to a 0 index (19.9 years), while the income component suffered a slight decrease.

(3) The HDI increased from 0.232 to 0.302 between 1890 and 1895 - a figure that was still below that of 1877 - because, although the income and literacy components in 1895 exceeded the 1877 indices, the figure for life expectancy in 1895 (0.155-29.2 years) was still well below that of 1877 (0.277-36.5 years).

(4) In 1900, the indicator reached the same figure as in $1877(0.316)$, since the combined increase in income and literacy placed it at the initial level despite the fact that life expectancy (0.175-30.4 years) was still lower than in 1877 (0.277-36.5 years).

(5) Finally, the 1910 index (0.395) was above that of 1877 (0.316) because income and literacy continued to improve and life expectancy $(0.320$ 39.1 years) was already higher than that of 1877 (0.277-36.5 years).

Thus, taking the HDI as an indicator, miners' welfare deteriorated between 1876 and 1900, but improved at the beginning of the $20^{\text {th }}$ century. This conclusion clashes with the one for real wages, since using the latter, miners' living standard became worse only between 1883 and 1890 . We are faced with a dilemma that is as old as the debate between "pessimists» and "optimists»: the relative weighting of welfare components, income and life expectancy in this case ${ }^{40}$. During the 1980s, Williamson (1984) tried to solve the problem by estimating what he called the "real living standard», an adjustment between the increased life expectancy and the extra future consumption (Williamson 1984). The calculation turned out to be optimistic because it was based on the life expectancy of England as a whole provided by Wrigley and Schofield and on the real wages calculated by Williamson himself, which grew by 100 per cent during the Industrial Revolution.

40 In the 1920s, Clapham argued that wage growth made up for the deterioration of other living standard elements among the British working class, whereas Hammond claimed just the opposite. The same happened in the 1950s and 1960s because, either explicitly or implicitly, the "optimists» (Asthon, Hartwell, and so on) supported Clapham's point of view and the "pessimists» (Hobsbawm, Thompson, and so on) that of Hammond. 
The outlook changed in the 1990s, as the data offered by Szreter and Mooney for life expectancy in English and Welsh industrial cities are pessimistic and the new series of real wages offered by Feinstein only rose by 30 per cent, so that, as this author argued, the increased income does not seem to have compensated for the decrease in life expectancy (Szreter and Mooney 1998; Feinstein 1998). This point of view, which seems reasonable in the British case, also makes sense in the case studied here, since the real wages paid to Biscayan miners between 1876 and the beginning of the 20th century grew by 12 per cent, while life expectancy in 1877 fell by 16 years during the 1880 s and 6-7 years in the 1890s, the level of 1877 only being recovered during the first 5 years of the $20^{\text {th }}$ century.

It would have been desirable to construct HDIs for miners in other Spanish regions in order to compare them with that of Biscayan miners, but this was impossible because, in the case of the Alquifes or Río Tinto mines, we do not know the real wage, the average family size or the life expectancy ${ }^{41}$ and, in the Cartagena mining industry, we know the life expectancy in El Beal, which reached a lower level than that of Biscayan mines (18.2 years in 1890 and 20.5 in 1895), but not the real wage or the average family size (Navarro Ortiz et al. 2004). However, it is possible to compare the HDI of Biscayan miners with the figures Escudero and Simón have estimated for Spain, though this would require a reconstruction of the latter with minimum and maximum life expectancy values of 19.9 and 85 years - instead of 25 and 85 - for the purpose of homogenising it with that of the miners (Escudero \& Simón 2003). After making this adjustment, the HDI of miners is situated below the Spanish index during the 1880s ( 0.232 as opposed to $0.310)$, the $1890 \mathrm{~s}$ (0.302 as opposed to 0.314$)$ and also in $1900(0.316$ as opposed to 0.399). The main reason lies in life expectancy although, as previously noted, the fact that miners' HDI is biased downward on the income side surely has an influence too.

The third indicator of miners' welfare, average height, has yet to be analysed. Some of the anthropometric series for the industrialisation period have been criticised because they come from biased sources, as military service was not compulsory ${ }^{42}$. However, after 30 years of anthropometric research, it hardly seems arguable that height is subject to cycles and that, although it contains a genetic load, that load is potential and can be altered by three factors, which, along with the genetic component, model it until the individual is 20-21 years old. These factors are: nutrition, morbidity and physical debilitation, as height results from the «net nutritional input», the difference between the "gross nutritional input» - the nutrients ingested - and the energy consumed via basal metabolism, physical activity

41 The excellent books of Cohen (1987), Harvey (1981) and Arenas Posadas (2000) do not contain this information.

${ }^{42}$ For the British case, for example, see Voth (2004). 
and diseases ${ }^{43}$. Height thus becomes a synthetic indicator of what Komlos calls the «biological living standard", since nutrition is associated with real wages, morbidity and physical debilitation reflecting other welfare components (epidemiological environment, public health level and working conditions). On the other hand, the factors modelling height are especially sensitive during the early years of life and above all during the jump towards adolescence because, whereas other unfavourable conditions present during the childhood period can be compensated later, they become irreversible when they appear between the age of 13 and 17 years (see Eveleth 1985; Tanner 1990; Komlos and Baten 2004).

The height series for the mining town of San Salvador del Valle (Figure 4) does not show biases because, as we have already said, all the conscripts were measured - including those who paid their «redemption» later — the series is standardised at 21 years of age and, in addition, nearly 93 per cent of those measured are registered as jornaleros (mine workers). There is, however, a problem. Between 1876 and 1911, half of the conscripts appear as born in San Salvador or in towns located in the mining and industrial area, while the other half are registered as born outside Biscay. The studies carried out by Pérez Castroviejo and Arbaiza show that most of the immigrants were families who found themselves in the most problematic period of their life cycle, that is, they had very young children (Pérez Castroviejo 1986; Arbaiza 1994). Therefore - and although it is impossible to know the exact proportion of conscripts born outside Biscay who spent all or part of their childhood and/or adolescence in the mining area - it seems logical to assume that most of them did, which is why we decided to use the average height of all the conscripts ${ }^{44}$.

As can be observed in Table A2 and in Figure 4 (standardised series at 21 years of age), the youngsters in the first cohort (measured between 1876 and 1880) had an average height of 163.65 centimetres and the following five cohorts (measured between 1881 and 1905) were shorter than the first one. The youngsters measured between 1876 and 1880 had been born between 1856 and 1860, and therefore their childhood and adolescence took place before the start of the mining «boom» in 1876. In contrast, the following five cohorts (measured between 1881 and 1905) spent their childhood and adolescence between 1876 and 1901, a period characterised by a diet poor in protein, high morbidity and worse labour conditions than those that existed

43 The literature on anthropometry is very wide-ranging. For this reason, we will only mention some works that we consider of special relevance: Fogel et al. (1982), Eveleth (1985), Tanner (1990), Floud et al. (1990), Eveleth and Tanner (1990), Nicholas and Steckel (1991), Komlos (1994), Steckel (1995), Steckel and Floud (1997), Fogel (2004), Steckel and Rose (2003), Komlos and Baten (1998, 2004).

${ }^{44}$ In any case, height fell both among those born in San Salvador and among those born outside Biscay, though the decrease was somewhat greater among the latter. 
since the beginning of the century. All of these aspects would explain the decrease in height with respect to the first cohort ${ }^{45}$.

Table A2 and Figure 4 show that the seventh cohort (measured between 1907 and 1911) exceeded the height of the first one (164.07 centimetres as opposed to 163.65 centimetres). The youngsters spent nearly all their childhood during the 1890s and their adolescence between 1902 and 1906, a period characterised by an increased real wage, better nutrition, lower morbidity and better labour conditions ${ }^{46}$. Thus, using height as an indicator, miners' welfare deteriorated between 1876 and the end of the $19^{\text {th }}$ century, but improved at the beginning of the $20^{\text {th }}$ century. This conclusion is in keeping with the one produced by the HDI, but differs from the conclusion drawn from the evolution of real wages (fall in the standard of living only between 1883 and 1890). Comparing all three indicators therefore proves to be more fruitful than using wages alone and reinforces the idea that wages can hide the behaviour of other welfare components.

We can only compare the evolution in the height of Biscayan miners with that of miners in Murcia since no anthropometric studies have been carried out in other mining regions. The height of miners in Cartagena and Mazarrón fell much more than that of Biscayan miners ( 3 vs. 1.62 centimetres) between the 1860 s and the end of the $19^{\text {th }}$ century, the height of miners in Cartagena having gone down to 157-158 centimetres during the 1880s and 1890s (Martínez Carrión 2005). This greater deterioration in the «biological living standard» was probably a consequence of the extremely high percentage of child work in a mining industry that was additionally underground - 33 per cent of the workers in the lead mines of Cartagena were children between 8 and 16 years of age (Pérez de Perceval and Sánchez Picón 2005). It is equally worth highlighting that the as yet unpublished Spanish height series calculated by Martínez Carrión also shows a decrease in the height of those born between 1850 and 1875 (measured between 1870 and 1895) and this is also the case with the regional series of the South-East, Castile-León, Andalusia, Catalonia, Madrid and the Valencian Autonomous Community ${ }^{47}$

45 Regarding nutrition, Table 1 shows that the diet of miners was poor in protein until the early $20^{\text {th }}$ century because of the predominance of bread, pulses and potatoes. Moreover - as we saw when dealing with the evolution of real wages — food consumption decreased during the 1880 s. As for morbidity, it suffices to mention that life expectancy went down between 1877 and 1900 (Table 2). Finally, taking the daily working hours and the number of days worked as indicators of labour conditions, the working day was 12 hours between 1876 and 1890 and 10 hours between 1891 and 1910 and, until 1904, every day was a working day with the exception of 16 religious holidays.

${ }^{46}$ It can be seen in Table A1 and in Figure 3 that the real wage grew since the late $19^{\text {th }}$ century. In his study of the nutrition of the Biscayan working class during the industrialisation period, Pérez Castroviejo (2000) demonstrates how the diet improved since the late $19^{\text {th }}$ or early $20^{\text {th }}$ century with increased consumption of meat and new products such as fish, eggs and milk (see Table 1). The reduction in morbidity becomes visible in life expectancy (Table 2) and after 1904, the number of days worked fell following the introduction of the Sunday Rest Act.

47 The Spanish series in Martínez Carrión and María Dolores (under evaluation at the moment); Levante in Martínez Carrión and Pérez-Castejón 1998; Castile-León in Hernández and 


\section{THE LIVING STANDARD OF BISCAYAN MINERS (1914-1936)}

It can be seen in Figure 3 that the real wages of miners decreased between 1916 and 1920 because, although the daily rate improved following several strikes, the inflationist "gap» caused by the Great War (Figure 2) reduced their purchasing power. What is more, a flu pandemic affected the whole of Spain between 1918 and 1919, and therefore it makes sense to argue that miners' welfare deteriorated between 1916 and 1920. The HDI (Table 2) does not reflect this because the index for 1910 is followed by the one corresponding to 1925 , as it turned out to be impossible for us to calculate the 1920 index due to lack of data for life expectancy. Nevertheless, the San Salvador del Valle conscripts measured between 1917 and 1920 lost 0.51 centimetres with respect to the preceding cohort (Table A2 and Figure 4). Since their teenage years, or some of them, coincided with World War I, this drop would be the reflection of poorer nutrition and a higher morbidity rate.

The three indicators show that the living standard of miners improved after 1920. From that year to 1936, nominal wages grew at an average cumulative rate of 1.54 per cent, precisely when the demand derived from the work factor plummeted following the fall in the demand for Biscayan iron ore $^{48}$. This evolution of wages must be explained by the existence of a labour market that was now characterised by a bilateral monopoly, in the context of which wages were determined in advance as a result of the negotiation between employers and unions. In 1919, the Sindicato Minero (Miners' Union) persuaded the Cámara Minera (Chamber of Mining) to accept the establishment of a minimum wage below which enterprises were not allowed to hire workers. The agreement also stipulated that wages would increase or decrease according to the price of sustenance. In 1922, the Sindicato Minero - controlled by a socialist majority - accepted a reduction in the wage agreed upon in 1919. This decision led to clashes with the communists as a result of which several people died. Nevertheless, the union managed to increase the minimum wage in 1924 and $1930^{49}$. It is worth highlighting that the growth of wages modified the distribution of added value in a substantial way (Table 4).

It must be remembered that real wages increased modestly (at an average cumulative annual rate of 0.35 per cent) during the expansion cycle of the mining industry. Between 1920 and 1936, however, the growth was considerable (2.65 per cent) and similar to the one calculated by Maluquer de

\footnotetext{
(F'note continued)

Moreno Lázaro (2009); Catalonia in Ramon-Muñoz (2009); Andalusia in Cámara (2009); Madrid in García Montero (2009); and the Valencian Autonomous Community in Puche Gil (2009).

48 A total of 12,000 workers were active in this sector in 1913; an average of only 5,700 were employed between 1920 and 1936.

49 For a history of the new labour relations in the mining area, see Escudero (2001).
} 
TABLE 4

ADDED VALUE DISTRIBUTION IN THE BISCAYAN IRON MINING INDUSTRY (1876-1936)

\begin{tabular}{|l|c|c|}
\hline Period & Capital factor reward (\%) & Labour factor reward (\%) \\
\hline $1876-1913$ & 60 & 40 \\
\hline $1920-1936$ & 30 & 70 \\
\hline
\end{tabular}

Source: Escudero (1998, pp. 282-285).

Motes for average wages in Spain as a whole (2 per cent), wages that, as Rosés \& Sánchez Alonso have demonstrated, experienced a strong convergence process after World War I (Rosés and Sánchez Alonso 2004; Maluquer de Motes 2005).

In addition, the HDI (Table 2) shows a higher welfare index, which increased from 0.305 in 1910 to 0.501 in 1930 as a result of the improvement in its three components, particularly life expectancy, which «jumped» from the 0.320 index (39.1 years) to a 0.507 index (50.3 years). This is closely linked to better nutrition, bigger investments to improve sanitary conditions, the disappearance of overcrowding in private homes and increased public expenditure on preventive measures, especially during Primo de Rivera's dictatorship ${ }^{50}$. Finally, height (Table A2 and Figure 4) shows an increase of 1.76 centimetres among the cohorts of conscripts measured between 1907 and 1910 and between 1932 and 1936, which is a reflection of the improvements achieved in the areas of nutrition, health and labour - the eight-hour working day was introduced in 1919 and piecework practically disappeared during the 1920 s as a consequence of the increase in real wages.

\section{CONCLUSIONS}

Research into working-class living standards during the industrialisation period has shown that wages do not cover all welfare elements - for example, working conditions, leisure time or «access rights» needed to make one prosper (health, education and freedom). This is why some of the published works have compared wages - or per capita income — with other indicators. Following this line of research, we have built three indicators of Biscayan miners' welfare between 1876 and 1936 (real wages, HDI and height), which have then been compared obtaining the results summarised below:

(1) Using wages as an indicator, the living standard of miners improved modestly between 1876 and 1913, but deteriorated during the 1883-1890

50 See Pérez Castroviejo (2005b) on nutrition, housing, and larger municipal expenses. On the greater expenses assumed by the State, see Robles et al. (1996). 
period. In contrast, HDI and height show a fall between 1876 and the end of the $19^{\text {th }}$ century or at the beginning of the $20^{\text {th }}$ century. This is because wages do not reflect the deterioration of two living standard components (health and working conditions).

(2) All three indicators show that miners' welfare improved modestly between the beginning of the $20^{\text {th }}$ century and 1915 . However, it deteriorated between 1916 and 1920 due to "exogenous» causes derived from World War I (the inflationist «gap» and the flu pandemic).

(3) Real wages, HDI, and height all demonstrate that the living standard of miners improved considerably between 1921 and 1936.

These conclusions are in line with recent research studies about workers' welfare during the Industrial Revolution. Referring specifically to the British case, real wages grew modestly; life expectancy decreased; working conditions became worse; and so did the «biological living standard». This tips the balance towards pessimism, though no one can deny that industrialisation eventually improved the living standard of workers ${ }^{51}$. The case of Biscayan miners shows a similar picture: pessimism during the first 25 years of mining industry expansion and optimism later.

Another contribution made by this paper, which in our view also represents an innovation, lies in the fact that we have related the high morbimortality in the working-class neighbourhoods inhabited by miners in Biscay to the market failures derived from urban development, which does not appear explicitly in the works focused on living standards during the Industrial Revolution. These market failures were known to the liberal politicians because the hygienists had demanded the State's intervention to correct them or, at least, to palliate them. Nevertheless, it took the town Councils in the mining areas of Bilbao - and of Spain as a whole - more than twenty years to put into practice the measures proposed by the hygienist doctors, this being an issue that deserves further research.

To conclude, we would like to highlight the fact that comparing several indicators is an excellent way to progress in the study of living standards during the industrialisation period and encourage Spanish colleagues to carry out monographs in which this methodology can be used.

\section{REFERENCES}

ArbaizA, M. (1994): «Movimientos Migratorios y Economías Familiares en el Norte de España (1877-1910)». Boletín de la Asociación de Demografía Histórica XII-XIII, pp. 93-194.

51 For the state of the art regarding the living standards of the British working class during the Industrial Revolution, see Escudero (2002) and Voth (2004). 
Arbaiza, M. (1995): «Mortalidad y Condiciones de Vida de los Trabajadores de la Industria Vizcaína del Siglo XIX». Revista de Historia Industrial 8, pp. 65-98.

Arbaiza, M.; Guerrero, A., and Pareja, A. (1996): «Mundo Rural y Mundo Urbano en la Transición de la Mortalidad Vizcaína (1770-1930)». Boletín de la Asociación de Demografía Histórica XIV, pp. 19-55.

Arenas Posadas, C. (2000): Empresa, Mercados, Mina y Mineros. Río Tinto, 1873-1936. Huelva: Publicaciones de la Universidad de Huelva.

Astorga, P.; Berges, A. R., and Fitzgerald, V. (2005): "The Standard of Living in Latin America during the Twentieth Century». Economic History Review LVIII (4), pp. 765-796.

Ballesteros, E. (1997): «UnaEstimación del Coste de la Vida en España, 1861-1936». Revista de Historia Económica XV (2), pp. 363-395.

Bringas, A. (2000): La Productividad de los Factores en la Agricultura Española, 1752-1935. Madrid: Servicio de Publicaciones del Banco de España.

BurnetT, J. (1980): A Social History of Housing, 1850-1970. London: Methuen.

Cámara, A. D. (2009): "Long-Term Trends in Height in Rural Eastern Andalusia (1750-1950)». Revista de Historia Agraria 47, pp. 45-67.

CLARK, G. (2001): «Farm Wages and Living Standards in the Industrial Revolution: England, 1670-1869». Economic History Review 54 (3), pp. 477-505.

Cohen, A. (1987): El Marquesado del Zenete, Tierra de Minas. Transición al Capitalismo y Dinámica Demográfica (1870-1925). Granada: Diputación de Granada.

Costa, D., and Steckel, R. H. (1997): «Long-Term Trends in Health, Welfare and Economic Growth in the United States», in R. H. Steckel, and R. Floud (eds), Health and Welfare during Industrialization. Chicago, I. L.: University of Chicago Press, pp. 47-65.

CRAFTS, N. F. R. (1985): «English Workers' Real Wages during the Industrial Revolution: Some Remaining Problems». Journal of Economic History 45, pp. 139-144.

Crafts, N. F. R. (1997a): «Some Dimensions of the Quality of Life during the British Industrial Revolution». Economic History Review 50, pp. 617-639.

CRAFTS, N. F. R. (1997b): «The Human Development Index and Changes in Standard of Living: Some Historical Comparisons». European Review of Economic History I, pp. 299-322.

Crafts, N. F. R. (2002): «The Human Development Index: 1870-1999: Some Revised Estimates». European Review of Economic History 6, pp. 395-405.

Dasgupta, P. (1993): An inquiry Into Well-Being Destitution. Oxford: Clarendon Press.

DesaI, M. (1991): «Human Development: Concepts and Measurement». European Economic Review 35, pp. 350-357.

Domingo Herández, M. M. (2008): Las Casas Baratas en Vizcaya. Bilbao: Bilbao Bizcaia Kutxa.

Dominguez Martin, R., and Guijarro Garvi, M. (2000): «Evolución de las Disparidades Espaciales del Bienestar en España, 1860-1930. El Índice Físico de Calidad de Vida». Revista de Historia Económica 1, pp. 109-138.

Escudero, A. (1998): Minería e Industrialización de Vizcaya. Barcelona: Crítica.

Escudero, A. (2001): «Mercado de Trabajo, Salarios y Distribución de la Renta en las Minas de Vizcaya (1876-1936)», in C. Arenas, A. Florencio, and J. Pons (eds), Trabajo y Relaciones Laborales en la España Contemporánea. Sevilla: Universidad de Sevilla, pp. 169-187.

Escudero, A. (2002): «Volviendo a un Viejo Debate: el Nivel de Vida de la Clase Obrera Británica Durante la Revolución Industrial». Revista de Historia Industrial 21, pp. 13-60.

Escudero, A., and Simón, H. (2003): «El bienestar en España: una Perspectiva de Largo Plazo (1850-1992)». Revista de Historia Económica 3, pp. 525-565. 
Eveleth, P. B. (1985): «Nutritional Implications of Differences in Adolescent Growth and Maturation and in Adult Body Size», in C. Blaxter, and J. C. Waterlow (eds), Nutritional Adaptation in Man. London: Jonh Cibbey, pp. 13-29.

Eveleth, P. B., and Tanner, J. M. (1990): Worldwide Variation in Human Growth. Cambridge: Cambridge University Press.

Federico, G., and Toniolo, G. (1991): «Italy», in R. Sylla, and G. Toniolo (eds), Patterns of European Industrialization. The Nineteenth Century. London: Routledge, pp. 197-218.

Feinstein, C. H. (1998): «Pessimism Perpetuated: Real Wages and the Standard of Living in Britain During and After the Industrial Revolution». Journal of Economic History 58, pp. 625-658.

Fernández de Pinedo, E. (1992): «Beneficios, Salarios y Nivel de Vida Obrero en una Gran Empresa Siderúrgica Vasca, Altos Hornos de Vizcaya (1902-1927). Una Primera Aproximación». Revista de Historia Industrial 1, pp. 127-157.

FlinN, M. W. (1974): «Trends in Real Wages, 1750-1850». Economic History Review 37, pp. 395-412.

Floud, R.; Watcher, K., and Gregory, A. (1990): Height, Health and History. Nutritional Status in the United Kingdom, 1750-1980. Cambridge: Cambridge University Press.

Fogel, R. W.; Engerman, S. L., and Trusell, J. (1982): «Exploring the Uses of Data on Height: The Analysis of Long-Term Trends in Nutrition, Labor, Welfare and Labor Productivity». Social Science History 6, pp. 401-421.

Fogel, R. W. (2004): The Escape from Hunger and Premature Death, 1700-2100. Europe, America and the Third World. Cambridge: Cambridge University Press.

Fusi, J. P. (1975): Política Obrera en el País Vasco, 1880-1923. Madrid: Turner.

García Montero, H. (2009): «Antropometría y Niveles de Vida en el Madrid Rural, 1837-1915». Revista de Historia Agraria 47, pp. 95-117.

Garrabou, R., and Tello, E. (2002): «Salario Como Coste, Salario Como Ingreso: El Precio de Los Jornales Agrícolas en la Cataluña contemporánea, 1727-1930», in J. M. Martínez Carrión (ed.), El Nivel de Vida en la España Rural, Siglos XVIII-XX. Alicante: Publicaciones de la Universidad de Alicante, pp. 113-182.

González Ugarte, M. E. (1994): «Mortalidad e Industrialización en el País Vasco. Vizcaya, 1860-1936». Boletín de la Asociación de Demografía Histórica XII, pp. 35-53.

Harvey, CH. E. (1981): The Rio Tinto Company. Penzance, Cornwall: Alison Hodhe.

Hernández, R., and Moreno Lázaro, J. (2009): «El Nivel de Vida en el Medio Rural de Castilla y León. Una Constatación Antropométrica, 1840-1970. Revista de Historia Agraria 47, pp. 143-166.

HorLings, E., and Smits, J. P. (1988): «The Quality of Life in the Netherlands: 1800-1913. Experiments in Measurement and Aggregation», in J. Komlos, and J. Baten (eds), Studies on Biological Standard of Living in Comparative Perspective. Stuttgart: Franz Steiner Verlag, pp. 321-343.

Horrel, S. (1996): «Home Demand and British Industrialisation». Journal of Economic History 56, pp. 561-604.

Huck, P. (1995): «Infant Mortality and Living Standards of English Workers During the Industrial Revolution». Journal of Economic History 55, pp. 528-597.

Komlos, J. (1994): Stature, Living Standard and Economic Development: Essays in Anthropometric History. Chicago, I. L.: University of Chicago Press.

Komlos, J., and Baten, J. (eds) (1998): The Biological Standard of Living in Comparative Perspective. Stuttgart: Franz Steiner.

Komlos, J., and Baten, J. (eds) (2004): «Special Issue: Recent Research in Anthropometric History». Social Science History 28 (2), pp. 191-350. 
Kuh, D., and Davey Smith, G. (1993): «When is Mortality Risk Determined? Historical Insights into a Current Debate». Social History of Medicine 6, pp. 101-123.

Lana Berasaín, J. M. (2005) «Aproximación a los Salarios Reales en la Navarra Rural, 1785-1945». VIII Congreso de la Asociación Española de Historia Económica, available at http://www.usc.es/es/congresos/histec05/a1.jsp

Lindert, P., and Williamson, J. (1983): «English Workers Living Standards during the Industrial Revolution: A New Look». Economic History Review 36, pp. 1-25.

Maddison, A. (1995): Monitoring the World Economy 1820-1992. Paris: OECD.

Maluquer de Motes, J. (2005): "Trabajo y relaciones laborales» and "Consumo y precios», in A. Carreras, and X. Tafunell (eds), Estadísticas históricas de España, siglos XIX-XX. Bilbao: Fundación BBVA, pp. 1.151-1.377.

Martínez Carrión, J. M. (2005): «Estatura, Salud y Nivel de Vida en la Minería del Sudeste Española, 1830-1936». Revista de Demografía Histórica XXIII (1), pp. 177-210.

Martínez Carrión, J. M., and PÉrez-Castejón, J. J. (1998): «Height and Standard of Living in Spain, 1860-1969: Evidence from the Southeastern Region», in J. Komlos, and J. Baten (eds), The Biological Standard of Living in Comparative Perspective. Stuttgart: Franz Steiner, pp. 344-358.

Martínez Carrión, J. M., and Puche-Gil, J. (2009): «Alfabetización, Bienestar Biológico y Desigualdad: la Comunidad Valenciana, 1850-1970». Revista de Historia Agraria 47, pp. 167-186.

Martínez Carrión, J. M., and María Dolores, R. (underevaluation): «The Relationship Between Height and Economic Development in Spain, 1850-1958». Economics and Human Biology.

Martínez Carrión, J. M., and Moreno Lázaro, J. (2007): «Was There and Urban Height Penalty in Spain, 1840-1913». Economics and Human Biology 5 (1), pp. 144-164.

Martínez Soto, A. P. (2005): «Salarios y Niveles de Vida en Las Zonas Mineras de Murcia, 1874-1935». VIII Congreso de la Asociación Española de Historia Económica, available at http://www.usc.es/es/congresos/histec05/a1.jsp

Molina DE Dios, R. (2003): Treball Intensiu, Treballadors Polivalents (Treball, Salaris i Cost de la Vida, Mallorca, 1860-1936). Mallorca: Govern de les Illes Balears.

Moreno Lázaro, J. (2006): «El Nivel de Vida en la España Atrasada Entre 1800 y 1936. El caso de Palencia». Investigaciones de Historia Económica 4, pp. 9-50.

Navarro Ortiz, D.; Martínez Soto, A. P., and Pérez de Perceval, M. A. (2004): La Vida en la Sierra Minera de Cartagena. Evolución Demográfica de la Diputación de El Beal, 1880-1970. Murcia: Ediciones Laborum.

Nicholas, S., and Steckel, R. (1991): «Heights and Living Standards of English Workers During the Early Years of Industrialisation, 1770-1815». Journal of Economic History 51, pp. 937-957.

Noorbakнsh, F. (1998): «The Human Development Index: Some Technical Issues and Alternative Indices». Journal of International Development 10, pp. 589-605.

Norhdaus, W., and Tobin, J. (1973): «Is Growth Obsolete?», in M. Moss (ed.), The Measurement of Economic and Social Performance. Cambridge, MA: NBER Book Series Studies in Income and Wealth, pp. 509-564.

NúÑEz, C. E. (1992): La Fuente de la Riqueza. Educación y Desarrollo Económico en la España Contemporánea. Madrid: Alianza Universidad.

Pérez Castroviejo, P. M. (1986): «La Inmigración, Factor Clave en el Crecimiento Demográfico de la Cuenca Minera vizcaína: el caso de Santurce-Ortuella, 1852-1910». University of the Basque Country, Doctoral thesis.

Pérez Castroviejo, P. M. (1992): Clase Obrera y Niveles de Vida en Las Primeras Fases de la Industrialización Vizcaína. Madrid: Ministerio de Trabajo y Seguridad Social. 
Pérez Castroviejo, P. M. (1994): «Aproximación al Estudio de la Vivienda de Los Trabajadores Mineros Vizcaínos». Áreas, Revista de Ciencias Sociales 16, pp. 177-194.

Pérez Castroviejo, P. M. (2000): «Consumo, Dieta y Nutrición de Grupos Populares. La Alimentación Durante la Industrialización de Vizcaya». Zainak 20, pp. 211-226.

Pérez Castroviejo, P. M. (2005): «Niveles de Bienestar de la Población Minera Vizcaína. Factores que Contribuyeron al Descenso de la Mortalidad, 1876-1936». Revista de Demografía Histórica XXIII (I), pp. 71-105.

Pérez Castroviejo, P. M. (2006): «Poder Adquisitivo y Calidad de Vida de los Trabajadores Vizcaínos, 1876-1936». Revista de Historia Industrial 30 (1), pp. 103-143.

Pérez Castroviejo, P. M., and Tusell, F. (2007): «Using Overlapping and Incomplete Time Series for the Estimation of Cost of Living Indices». Review of Income and Wealth, Series 53 (4), pp. 673-691.

Pérez Fuentes, P. (1991): «El Discurso Higienista y la Moralización de la Clase Obrera en la Primera Industrialización Vasca». Historia Contemporánea 5, pp. 127-158.

Pérez Fuentes, P. (1993): Vivir y Morir en las Minas. Estrategias Familiares y Relaciones de Género en la Primera Industrialización Vizcaína. Bilbao: Universidad del País Vasco.

Pérez Fuentes, P. (2003): «Ganadores de Pan y Amas de Casa: Los Límites del Modelo de Male Breadwinner Family. Vizcaya, 1900-1965», in C. Sarasúa, and L. Gálvez (eds), Privilegios o Eficiencia? Mujeres y Hombres en los Mercados de Trabajo. Alicante: Publicaciones de la Universidad de Alicante, pp. 217-237.

Pérez de Perceval, M. A., and Sánchez Picón, A. (2005): «El Trabajo Infantil en la Minería Española, 1850-1940». VIII Congreso de la Asociación Española de Historia Económica, available at http://www.usc.es/es/congresos/histec05/a1.jsp

Pérez Picazo, M. T. (2005): «El Mercado de Factores en la Agricultura Murciana Durante el siglo XIX». Investigaciones de Historia Económica 2, pp. 39-75.

Prados de la Escosura, L. (2003): El Progreso Económico de España (1850-2000). Madrid: Fundación BBVA.

Puche GiL, J. (2009): Evolución de los 'niveles de vida biológicos en la Comunidad Valenciana, 1840-1948. Tesis Doctoral Dirigida por José Miguel Martínez Carrión y Defendida en la Universidad Pablo de Olavide de Sevilla en Septiembre de 2009.

Ramon-Muñoz, J. M. (2009): «Bienestar Biológico y Crecimiento Agrario en la Cataluña Rural, 1840-1936». Revista de Historia Agraria 47, pp. 119-142.

Robles, E.; G. Benavides, F., and Bernabeu, J. (1996): «La Transición Sanitaria en España desde 1900 a 1990». Revista Española de Salud Pública 70 (2), pp. 226-249.

Rosés, J. R., and Sánchez Alonso, B. (2004): "Regional Wage Convergence in Spain 1850-1930». Explorations in Economic History 41 (4), pp. 404-425.

Rule, J. (1986): The Labouring Classes in Early Industrial England, 1750-1850. London: Longman Group Ltd.

SANDERSon, M. (1991): Education, Economic Change and Society in England 1780-1870. London \& Basingstoke: Macmillan.

Scholliers, P. (ed) (1989): Real Wages in $19^{\text {th }}$ and $20^{\text {th }}$ Century Europe. Historical and Comparative Perspectives. Oxford: Berg.

SEN, A. (1998): The Standard of Living. Cambridge: Cambridge University Press.

Sen, A. (2000): Freedom, Rationality and Social Choice. Oxford: Clarendon Press.

Simpson, J. (1995): "Real Wages and Labour Mobility in Spain, 1860-1936», in P. Scholliers, and V. Zamagni (eds), Labour's Reward. Real Wages and Economic Change in $19^{\text {th }}$ and $20^{\text {th }}$ Century Europe. Hants: Edward Elgar Publishing Company, pp. 182-200. 
Smith, L. B.; Rosen, K. T., and Fallis, G. (1988): «Recent Developments in Economic Models of Housing Markets». Journal of Economic Literature XXVI, pp. 29-64.

STECKEL, R. (1995): «Stature and the Standard of Living». Journal of Economic Literature 33, pp. 1903-1940.

Steckel, R., and Floud, R. (1997): Health and Welfare During Industrialization. Chicago, I. L.: University of Chicago Press.

Steckel, R., and Rose, J. R. (2003): The Backbone of History. Health and Nutrition in the Western Hemisphere. Cambridge: Cambridge University Press.

Streeten, P. (1994): «Human Development: Means and Ends». The American Economic Review 84 (2), pp. 232-237.

Szreter, S., and Mooney, G. (1998): «Urbanization, Mortality, and the Standard of Living Debate: New Estimates of the Expectation of Life in Nineteenth-Century British Cities». Economic History Review 51, pp. 84-112.

Tanner, J. M. (1990): Foetus Into Man: Physical Growth from Conception to Maturity. Cambridge, Mass.: Harvard University Press.

Williamson, J. G. (1984): «British Mortality and the Value of life». Population Studies 38, pp. 157-172.

Voтн, H. J. (2001): Time and Work in England, 1750-1830. Oxford: Oxford University Press.

Vотн, H. J. (2004): «Living Standards and the Urban Environment», in R. Floud, and P. Johnson (eds), The Cambridge Economic History of Modern Britain. Industrialisations 1700-1860. Cambridge: Cambridge University Press, pp. 268-293. 


\section{APPENDIX}

TABLE A1

REAL WAGES OF BISCAYAN MINERS (1876-1936)

\begin{tabular}{|c|c|c|c|c|}
\hline Years & $\begin{array}{c}\text { Nominal } \\
\text { wages (pesetas } \\
\text { per day) }\end{array}$ & $\begin{array}{c}\text { Nominal } \\
\text { wages (index } \\
\text { numbers) }\end{array}$ & $\begin{array}{l}\text { Cost of } \\
\text { living } \\
\text { index }\end{array}$ & $\begin{array}{c}\text { Real } \\
\text { wages } \\
\text { (pesetas) }\end{array}$ \\
\hline 1876 & 2.50 & 100 & 100 & 100 \\
\hline 1877 & 2.52 & 100 & 99 & 101 \\
\hline 1878 & 2.60 & 104 & 101 & 103 \\
\hline 1879 & 2.68 & 107 & 108 & 99 \\
\hline 1880 & 2.75 & 110 & 106 & 103 \\
\hline 1881 & 2.77 & 110 & 103 & 106 \\
\hline 1882 & 2.70 & 108 & 106 & 101 \\
\hline 1883 & 2.76 & 110 & 117 & 94 \\
\hline 1884 & 2.78 & 111 & 121 & 91 \\
\hline 1885 & 2.76 & 110 & 121 & 91 \\
\hline 1886 & 2.78 & 111 & 128 & 86 \\
\hline 1887 & 2.84 & 113 & 122 & 92 \\
\hline 1888 & 2.85 & 114 & 121 & 94 \\
\hline 1889 & 2.86 & 114 & 120 & 95 \\
\hline 1890 & 2.87 & 114 & 117 & 97 \\
\hline 1891 & 2.85 & 114 & 105 & 108 \\
\hline 1892 & 2.89 & 115 & 114 & 100 \\
\hline 1893 & 2.87 & 114 & 112 & 101 \\
\hline 1894 & 2.90 & 116 & 106 & 109 \\
\hline 1895 & 2.92 & 116 & 106 & 109 \\
\hline 1896 & 2.96 & 118 & 110 & 107 \\
\hline 1897 & 2.97 & 118 & 117 & 100 \\
\hline 1898 & 3.01 & 120 & 113 & 106 \\
\hline 1899 & 3.01 & 120 & 104 & 115 \\
\hline 1900 & 3 & 120 & 105 & 114 \\
\hline
\end{tabular}


TABLE A1 (Cont.)

\begin{tabular}{|c|c|c|c|c|}
\hline Years & $\begin{array}{c}\text { Nominal } \\
\text { wages (pesetas } \\
\text { per day) }\end{array}$ & $\begin{array}{c}\text { Nominal } \\
\text { wages (index } \\
\text { numbers) }\end{array}$ & $\begin{array}{l}\text { Cost of } \\
\text { living } \\
\text { index }\end{array}$ & $\begin{array}{c}\text { Real } \\
\text { wages } \\
\text { (pesetas) }\end{array}$ \\
\hline 1901 & 3.05 & 122 & 109 & 111 \\
\hline 1902 & 3.07 & 122 & 112 & 109 \\
\hline 1903 & 3.09 & 123 & 110 & 111 \\
\hline 1904 & 3.13 & 125 & 110 & 113 \\
\hline 1905 & 3.17 & 126 & 108 & 116 \\
\hline 1906 & 3.19 & 127 & 113 & 112 \\
\hline 1907 & 3.25 & 130 & 114 & 114 \\
\hline 1908 & 3.30 & 132 & 113 & 116 \\
\hline 1909 & 3.28 & 131 & 113 & 116 \\
\hline 1910 & 3.21 & 128 & 107 & 119 \\
\hline 1911 & 3.23 & 129 & 114 & 113 \\
\hline 1912 & 3.34 & 133 & 113 & 117 \\
\hline 1913 & 3.30 & 132 & 123 & 107 \\
\hline 1914 & 3.29 & 131 & 121 & 108 \\
\hline 1915 & 3.44 & 137 & 126 & 108 \\
\hline 1916 & 3.55 & 142 & 158 & 89 \\
\hline 1917 & 3.88 & 155 & 163 & 95 \\
\hline 1918 & 4.57 & 182 & 232 & 78 \\
\hline 1919 & 5.37 & 214 & 225 & 95 \\
\hline 1920 & 6.22 & 248 & 255 & 97 \\
\hline 1921 & 6.84 & 273 & 224 & 121 \\
\hline 1922 & 5.85 & 234 & 203 & 115 \\
\hline 1923 & 5.85 & 234 & 188 & 124 \\
\hline 1924 & 7 & 280 & 230 & 121 \\
\hline 1925 & 7.05 & 282 & 220 & 128 \\
\hline 1926 & 7.07 & 282 & 218 & 129 \\
\hline 1927 & 7.07 & 282 & 220 & 128 \\
\hline 1928 & 7.07 & 282 & 209 & 135 \\
\hline
\end{tabular}


TABLE A1 (Cont.)

\begin{tabular}{|l|c|c|c|c|}
\hline Years & $\begin{array}{c}\text { Nominal } \\
\text { wages (pesetas } \\
\text { per day) }\end{array}$ & $\begin{array}{c}\text { Nominal } \\
\text { wages (index } \\
\text { numbers) }\end{array}$ & $\begin{array}{c}\text { Cost of } \\
\text { living } \\
\text { index }\end{array}$ & $\begin{array}{c}\text { Real } \\
\text { wages } \\
\text { (pesetas) }\end{array}$ \\
\hline 1929 & 7.40 & 296 & 221 & 134 \\
\hline 1930 & 7.49 & 299 & 217 & 137 \\
\hline 1931 & 7.57 & 302 & 220 & 137 \\
\hline 1932 & 7.75 & 310 & 214 & 144 \\
\hline 1933 & 7.75 & 310 & 201 & 154 \\
\hline 1934 & 7.76 & 310 & 205 & 151 \\
\hline 1935 & 7.76 & 310 & 205 & 151 \\
\hline 1936 & 7.95 & 318 & 215 & 148 \\
\hline
\end{tabular}

Source: See section 2 of this paper.

TABLE A2

AVERAGE HEIGHT OF THE CONSCRIPTS MEASURED IN THE MINING TOWN OF SAN SALVADOR DEL VALLE (1876-1935; 5-YEARLY AVERAGES IN CENTIMETRES)

\begin{tabular}{|c|c|c|c|c|}
\hline Age & Birth & Conscription & Mean height & Standardisation at 21 years \\
\hline 20 & $1856-1860$ & $1876-1880$ & 163.1 & 163.65 \\
20 & $1861-1865$ & $1881-1885$ & 162.48 & 163.03 \\
19 & $1866-1870$ & $1885-1889$ & 161.16 & 162.16 \\
19 & $1871-1875$ & $1890-1894$ & 161.03 & 162.03 \\
19 & $1876-1880$ & $1895-1899$ & 161.9 & 162.90 \\
20 & $1881-1885$ & $1901-1905$ & 162.44 & 162.99 \\
21 & $1886-1890$ & $1907-1911$ & 164.07 & 164.07 \\
21 & $1891-1895$ & $1912-1916$ & 164.59 & 164.59 \\
21 & $1896-1900$ & $1917-1921$ & 164.08 & 164.08 \\
21 & $1901-1905$ & $1922-1926$ & 165.22 & 165.22 \\
21 & $1906-1910$ & $1927-1931$ & 166.12 & 166.12 \\
21 & $1911-1915$ & $1932-1936$ & 165.86 & 165.86 \\
\hline
\end{tabular}

Source: Actas de Clasificación y Alistamiento from San Salvador del Valle Council (Pérez Castroviejo 2006). 